\title{
KARAKTERISTIK PERILAKU AGRESIF REMAJA PADA SEKOLAH MENENGAH KEJURUAN
}

\author{
Yulvi Hardoni' ${ }^{*}$, Meri Neherta ${ }^{2}$, Rika Sarfika ${ }^{2}$ \\ ${ }^{1}$ Pascasarjana Fakultas Keperawatan, Universitas Andalas \\ ${ }^{2}$ Fakultas Keperawatan Universitas Andalas \\ *yulvihardoni74@gmail.com
}

\begin{abstract}
ABSTRAK
Masa remaja merupakan masa transisi dan akan memperlihatkan perilaku yang unik dan mengalami kesulitan mengelola emosi dan perilaku, sehingga salah satunya akan menyebabkan perilaku agresif. Berbagai dampak dapat terjadi akibat perilaku agresif yaitu seperti menurunnya prestasi belajar, hubungan sosial tidak baik, kecemasan, depresi dan bunuh diri. Penelitian ini bertujuan untuk mengetahui gambaran karakteristik perilaku agresif remaja berdasarkan aspek agresi fisik, verbal, kemarahan dan permusuhan pada sekolah menengah kejuruan "X di Kota Padang. Penelitian merupakan jenis penelitian kuantitatif dengan desain deskriptif. Teknik pengambilan sampel yaitu proportional random sampling dengan jumlah sampel sebanyak 164 siswa. Pengumpulan data perilaku agresif dengan menggunakan Buss-Perry Aggression Questionnaire Scale. Hasil penelitian menunjukkan rerata perilaku agresif remaja 86,74. Rerata aspek agresi fisik 26,98, agresi verbal 14,58, kemarahan 20,44 dan permusuhan 24,75. Perilaku agresif remaja sekolah menengah kejuruan di kota Padang cenderung tinggi dengan karakteristik yaitu permusuhan dan agresi fisik. Diharapkan perawat jiwa untuk memberikan latihan asertif, rational emotive behaviour therapy dan aggression replacement training pada remaja yang mengalami perilaku agresif.
\end{abstract}

Kata kunci: remaja, perilaku agresif, kecemasan

\section{THE AGGRESSIVE BEHAVIOR CHARACTERISTIC OF ADOLESCENT AT VOCATIONAL HIGH SCHOOL}

\begin{abstract}
Adolescent is a transition period and will show unique behavior and have difficulty in managing emotions and behavior so one of the effects is causing aggressive behavior. Various impacts can occur due to aggressive behavior, such as low learning achievement, bad social relations, anxiety, depression and suicide. This study aimed to describe the aggressive behavior characteristic of adolescent at vocational high school " $X$ " in Padang City. This study was quantitative research with descriptive design. The samples were chosen by proportional random sampling technique with a total sample of 164 students. The data of aggressive behavior were collected by using the Buss-Perry Aggression Questionnaire Scale. The results indicated that the average aggressive behavior of adolescent 86.74. The average phsycal aggression aspect is 26.98, verbal aggression is 14.58, anger is 20.44 and hostility is 24.75. Aggressive behavior of adolescent at vocational high school tended to be high with characteristic is hostility and phsycal aggression. It is expected that psychiatric nurses can provide assertive training, rational emotive behavior therapy and aggression replacement training for adolescent who experience aggressive behavior.
\end{abstract}

Keywords: adolescent, aggressive behavior, anxiety

\section{PENDAHULUAN}

Masa remaja merupakan masa transisi yang mengalami perubahan fisik dan kognitif yang signifikan (Santrock, 2011), tahap perkembangan yang unik usia $11-18$ tahun (Stuart 2016), mulai memiliki tantangan, keistimewaan, dan harapan (Martin, 2018), tahapan menuju kemandirian secara sosial, membentuk identitas, memiliki kemampuan orang dewasa serta kemampuan bernegosiasi (WHO, 2015). Jadi, remaja adalah kelompok usia antara kanak-kanak dengan dewasa awal yang mengalami proses kematangan fisik, psikologis dan sosial. Pada masa remaja bukan saja mencapai tugas perkembangan, tetapi juga harus mengatasi berbagai stressor (Shelton, Kesten, Zhang, \& Trestman, 2011), sehingga remaja memperlihatkan perilaku yang unik 
(Stuart, 2016), dan mengalami kesulitan mengelola emosi dan perilaku (Blakemore \& Mills, 2014; Holder \& Blaustein, 2014). Berbagai masalah psikososial dialami pada usia remaja seperti bersikap kasar, prestasi buruk, perilaku mengganggu, antisosial, depresi, ansietas dan bermusuhan (Stuart, 2016). Selain itu remaja juga berisiko terhadap pengangguran, perilaku agresif dan kriminalitas (Kusumaryani, 2017). Dari berbagai masalah yang dialami remaja tersebut salah satunya adalah masalah perilaku agresif.

Perilaku agresif adalah perilaku untuk mengancam dan dilakukan pada benda ataupun orang (Townsend, 2015), perilaku verbal ataupun fisik yang dapat membahayakan manusia dan makhluk hidup lainnya serta menyebabkan kesulitan, kerusakan, rasa sakit, atau merusak properti (Marcus, 2017), sedangkan menurut Anderson \& Bushman (2012) yaitu perilaku ditujukan pada individu lain dengan niat sengaja menyakiti. Jenis dari perilaku agresif remaja dibedakan dalam 3 bentuk yaitu perilaku agresif fisik, verbal, dan relasional (Saklofske \& Zeidner, 2009). Pendapat lain hampir sama yaitu perilaku agresif berupa agresif langsung dan tidak langsung, agresif aktif dan pasif, serta agresif verbal dan fisik (Rajasakran, Wong, Sinnappan, Pangiras, \& Koran, 2014). Sedangkan menurut Buss-Perry bahwa perilaku agresif terdiri dari 4 karakteristik, yaitu perilaku agresi fisik, verbal, kemarahan serta permusuhan (Gallagher \& Ashford, 2016).

Karakteristik perilaku berdasarkan aspekaspek, yang pertama adalah agresi fisik (physical aggression) yaitu merupakan perilaku menyerang orang lain dengan menggunakan bagian tubuh yang keras atau dengan menggunakan benda lain yang mengakibatkan korbannya luka fisik. Karakteristik kedua adalah agresi verbal (verbal aggression) yaitu merupakan perilaku verbal terhadap orang lain berupa ancaman atau penolakan, sehingga mengakibatkan korbannya luka secara psikis. Karakteristik ketiga adalah kemarahan (anger) yaitu respon emosional seseorang yang menunjukkan perasaan marah dan frustrasi. Karakteristik keempat adalah permusuhan (hostility) yaitu perilaku verbal yang diungkapkan seseorang secara implisit berupa perasaan curiga kepada orang lain dengan tujuan untuk memproteksi diri sendiri dari rangsangan yang dianggap berbahaya (Gallagher \& Ashford, 2016).

Beberapa penelitian tentang perilaku agresif yaitu di Nigeria bahwa $20,8 \%$ remaja mengalami agresif fisik dan $48,3 \%$ agresif verbal (Onukwufur, 2013), tahun 2015 di Amerika sebanyak $22,6 \%$ remaja melakukan pertarungan fisik (Laura, 2016). Menurut WHO tahun 2016 didunia diperkirakan 200.000 perilaku agresif terjadi pada remaja setiap tahunnya, serta penyebab kematian keempat kelompok remaja (WHO, 2016). Sedangkan di China remaja memiliki 4,31 kali kecenderungan mengalami perilaku agresif (Zhang et al., 2018). Sedangkan kejadian perilaku agresif di Indonesia, menurut penelitian Pitakasari, Kandar, \& Pambudi, (2017) bahwa 40,5\% remaja berperilaku agresif, penelitian Fasya \& Friska Amelia, (2017) bahwa 11,9\% remaja perilaku agresif kategori tinggi dan $75 \%$ remaja perilaku agresif sedang. Penelitian Sentana (2017), bahwa 2,96\% remaja agresivitas tinggi serta $81,48 \%$ remaja agresivitas sedang. Penelitian Enopadria bahwa $55,8 \%$ remaja perilaku agresif kategori tinggi dan $44,2 \%$ remaja perilaku agresif kategori rendah (Enopadria, 2018).

Perilaku agresif akan menimbulkan berbagai macam kerugian dan dampak negatif yaitu seperti rendahnya prestasi belajar dan tidak baiknya interaksi sosial dengan teman sebaya (Salmiati, 2015). Dampak lainnya yaitu kecemasan, depresi, masalah hukum, reaksi traumatis psikologis dan emosional, panik, fobia dan depresi (Hall, 2012), interaksi sosial buruk (Utami \& Nurhayati, 2019), dan ketidakberdayaan (Utami, Fadilah, \& Livana, 2019). Sedangkan dampak yang lebih berat yaitu remaja mengalami gejala positif skizotypal (Fagel \& Sonneville, 2013), risiko perilaku bunuh diri (Zhang et al., 2018), serta penyebab utama morbiditas dan mortalitas remaja di dunia yaitu sebesar 5,5\% kematian remaja disebabkan oleh perilaku agresif (Mokdad et al., 2016).

Sehubungan dengan adanya fenomena perilaku agresif dikalangan remaja dan berdampak sangat luas, maka peneliti memiliki ketertarikan mengetahui perilaku agresif remaja pada sekolah menengah kejuruan di Kota Padang. Tujuan penelitian ini adalah untuk mengetahui gambaran karakteristik perilaku agresif remaja pada sekolah 
menengah kejuruan " $X$ " di Kota Padang. Sehingga dapat bermanfaat sebagai pembanding dan landasan penelitian yang akan datang dengan ruang lingkup dan metodelogi yang sama ataupun merubah variabel dan tempat penelitian untuk pengembangan penelitian keperawatan.

\section{METODE}

Penelitian ini merupakan penelitian kuantitatif menggunakan desain deskriptif. Populasi penelitian ini adalah siswa sekolah menengah kejuruan "X" Kota Padang. Teknik pengambilan sampel yaitu proportional randam sampling dengan jumlah sampel sebanyak 164 orang. Pengumpulan data penelitian dilaksanakan pada bulan Maret sampai April 2019. Pengambilan data dilakukan dengan menggunakan kuesioner yang terdiri dari kuesioner data demografi (usia, jenis kelamin, kelas), dan kuesioner perilaku agresif Buss-Perry Aggression Questionnaire Scale yang dikembangkan oleh Buss A.H., dan Perry M (Buss \& Perry, 1992). Instrumen ini menggunakan scale-likert, dengan alternatif respon antara 1 sampai 5, yaitu "sangat tidak sesuai, tidak sesuai, kurang sesuai, sesuai dan sangat sesuai. Jumlah item pernyataan kuesioner berjumlah 29 item yang terdiri dari empat faktor yaitu agresi fisik (9 item), agresi verbal (5 item), kemarahan (7 item) dan permusuhan (8 item).

Instrumen $B A P Q$ telah dilakukan uji validitas dan reabilitas yaitu antara lain oleh ValdiviaPeralta et.al (2014) di Chili, Ivacevich \& Gabriela (2011) di Argentina, Turki, Evren, et.al (2011) di Portugis (Pechorro, Barroso, Poiares, Oliveira, \& Torrealday, 2016) dengan hasil menunjukkan valid. Peneliti juga telah melakukan uji validitas dan reabilitas kuesioner $B P A Q$ pada 60 siswa sekolah menengah kejuruan di Kota Padang, dengan hasil valid yaitu nilai $r$ hitung $\geq$ dari $r$ tabel $(0,264)$ dan reliabel dengan nilai koefisien realibiltas sebesar 0,872 .

Data diolah dan diproses menggunakan sistem program komputer (SPSS), serta data dianalisis secara univariat. Rentang skor variabel perilaku agresif yaitu 29 sampai 145, serta untuk karakteristik perilaku agresif berdasarkan aspek agresi fisik dengan rentang skor 9 sampai 45, agresi verbal dengan rentang skor 5 sampai 25 , kemarahan dengan rentang skor 7 sampai 35, serta permusuhan dengan rentang skor 8 sampai 40. Hasil interpretasi data variabel perilaku agresif yaitu semakin tinggi skor masing-masing aspek dan total skor perilaku agresif, maka semakin tinggi tingkat agresif yang dialami remaja, dengan hasil ukur mean.

Peneliti memperhatikan prinsip-prinsip dasar etik penelitian yang meliputi respect for autonomy, beneficience, nonmaleficience, anonymity, dan justice (Tobergte \& Curtis, 2013; Wallace \& Joyce, 2012). Peneliti telah mengikuti ethical clearence yang dilaksanakan oleh Komite Etika Penelitian Fakultas Kedokteran Universitas Andalas dengan surat keterangan lolos kaji etik (Ethical Clearence) nomor 088/KEP/FK/2019.

\section{HASIL}

Karakteristik umur responden dari hasil analisis yaitu didapatkan rata-rata umur responden adalah 16,28 tahun dengan standar deviasi 0,570 tahun. Umur responden yang termuda yaitu 15 tahun dan umur tertua 18 tahun. Dari hasil estimasi interval dapat disimpulkan bahwa 95\% diyakini rata-rata umur responden adalah antara 16,18 sampai dengan 16,39 tahun (Tabel 1).

Tabel 1 .

Karakteristik responden berdasarkan umur $(n=164)$

\begin{tabular}{cccccc}
\hline Variabel & Mean & SD & SE & Manimum-Maksimum & $95 \%$ CI \\
\hline Umur & 16,28 & 0,570 & 0,097 & $15-18$ & $16,18-16,39$ \\
\hline $\begin{array}{l}\text { Karakteristik responden menurut jenis kelamin } \\
\text { bahwa responden dengan jenis }\end{array}$ & $\begin{array}{l}\text { laki yaitu } 85 \text { orang }(51,8 \%) \text { dan jenis kelamin } \\
\text { perempuan yaitu 79 orang }(48,2 \%) \text {, tabel 2. }\end{array}$
\end{tabular}

Tabel 2.

Karakteristik responden berdasarkan jenis kelamin $(n=164)$

\begin{tabular}{lcc}
\hline \multicolumn{1}{c}{ Jenis kelamin } & Jumlah & Persentase \\
\hline Laki-laki & 85 & 51,8 \\
Perempuan & 79 & 48,2 \\
\hline
\end{tabular}


Rerata perilaku agresif remaja yaitu 86,74 dengan standar deviasi 11,889. Skor yang terendah yaitu 46 dan tertinggi 118. Dari hasil estimasi interval dapat disimpulkan bahwa
95\% diyakini rata-rata skor perilaku agresif responden adalah antara 84,91 sampai dengan 88,58 (tabel 3).

Tabel 3.

Perilaku agresif pada remaja $(\mathrm{n}=164)$

\begin{tabular}{|c|c|c|c|c|c|}
\hline Variabel & Mean & SD & SE & $\begin{array}{l}\text { Minimum - } \\
\text { Maksimum }\end{array}$ & $95 \%$ CI \\
\hline Perilaku Agresif & 86,74 & 11,889 & 0,928 & $46-118$ & $84,91-88,58$ \\
\hline
\end{tabular}

Tabel 4

Karakteristik perilaku agresif remaja $(n=164)$

\begin{tabular}{lccccc}
\hline \multicolumn{1}{c}{$\begin{array}{c}\text { Karakteritik } \\
\text { perilaku agresif }\end{array}$} & Mean & SD & SE & $\begin{array}{c}\text { Minimum - } \\
\text { Maksimum }\end{array}$ & 95\% CI \\
\hline Agresi Fisik & 26,98 & 4,540 & 0,355 & $15-37$ & $26,28-27,68$ \\
Agresi Verbal & 14,58 & 2,813 & 0,220 & $8-22$ & $14,15-15,01$ \\
Kemarahan & 20,44 & 4,442 & 0,347 & $10-31$ & $19,75-21,12$ \\
Permusuhan & 24,75 & 5,442 & 0,425 & $13-39$ & $23,91-25,59$ \\
\hline
\end{tabular}

\section{PEMBAHASAN}

Hasil penelitian sebagaimana yang terdapat pada tabel 3, menunjukkan bahwa remaja mengalami perilaku agresif dengan skor ratarata 86,74 . Skor rata-rata perilaku agresif ini didapat dari pengukuran dengan menggunakan Buss-Perry Aggression Questionnaire Scale (BPAQ) yang terdiri dari 29 item pernyataan dengan rentang nilai 29 sampai 145. Interpretasi dari hasil pengukuran dengan kuesioner $B P A Q$ yaitu semakin tinggi skor pengukuran yang diperoleh, maka semakin tinggi perilaku agresif yang dialami remaja. Berdasarkan hasil analisis dapat disimpulkan bahwa perilaku agresif yang dialami remaja di sekolah menengah kejuruan " $\mathrm{X}$ " Kota Padang cenderung tinggi karena semakin tinggi skor pengukuran yang diperoleh, maka semakin tinggi perilaku agresif yang dialami.

Perilaku agresif dalam penelitian ini yaitu suatu tindakan seseorang yang disengaja untuk menyakiti orang lain secara fisik ataupun psikologis (Saklofske \& Zeidner, 2009). Dan menurut Anderson, \& Bushman (2012) perilaku agresif yaitu perbuatan seseorang yang ditujukan dengan niat sengaja menyakiti atau mencelakakan (Allen \& Anderson, 2017). Sedangkan pendapat lain perilaku agresif diartikan sebagai perilaku verbal ataupun fisik yang dapat membahayakan serta menyebabkan kesulitan, kerusakan, rasa sakit dan merusak

benda (Marcus, 2017). Dan menurut
Townsend, yaitu perilaku sesorang yang bermaksud mengancam atau melukai perasaan dan dilakukan terhadap benda ataupun orang (Townsend, 2015).

Menurut Sigmund Freud (1920) yang dikenal dengan Freud's Instinct Theory of Aggression, bahwa agresi adalah naluri alami dan dapat terakumulasi dalam diri individu tanpa adanya rangsangan dari luar (Schultz \& Duane, 2016). Jika individu mengalami kesulitan menemukan cara melepaskan frustrasi melalui kegiatan positif akan cenderung berperilaku agresif (Kanne \& Mazurek, 2011). Sedangkan teori dorongan (drive theory) menurut Dollard, et.al (1939) bahwa agresi yaitu hasil dari frustrasi berlebihan dalam menanggapi tantangan untuk memenuhi kebutuhan dasar, jika kesulitan dalam mengkomunikasikannya atau kebutuhan dasar tidak terpenuhi, maka kecenderungan terjadinya agresi (Hayman, 2016). Dan menurut teori pembelajaran sosial (social learning theory) Albert Bandura (1973), agresi adalah perilaku yang dipelajari melalui fungsi sosial (Gentile, Coyne, \& Walsh, 2011).

Hasil penelitian ini sejalan dengan penelitian Naser (2014), bahwa rata-rata skor perilaku agresif remaja di Iran yaitu sebesar $63,61 \%$. Dan tidak jauh beda dengan penelitian Fitri, Intan, \& Luawo (2016) pada remaja di Jakarta 
bahwa $85,7 \%$ berada perilaku agresif pada rentang skor 68-106. Sedangkan penelitian Fasya \& Friska Amelia, (2017) menunjukkan bahwa sebesar $11,9 \%$ remaja termasuk perilaku agresif kategori tinggi dan sebesar 75\% remaja perilaku agresif sedang. Hasil ini konsisten juga dengan penelitian Sentana (2017), yaitu sebesar $81,48 \%$ remaja pada kategori agresivitas sedang. Pada penelitian di India menunjukkan hasil sebanyak $73 \%$ remaja laki-laki mengalami perilaku agresif sedang dan $32 \%$ perilaku agresif tinggi serta sebanyak $57 \%$ remaja perempuan mengalami perilaku agresif sedang dan $18,5 \%$ perilaku agresif tinggi (Kumari \& Kaur Kang, 2017). Hasil ini juga didukung dengan penelitian yang dilakukan di China bahwa remaja memiliki 4,31 kali kecenderungan mengalami perilaku agresif (Zhang et al., 2018).

Masih tingginya kecenderungan perilaku agresif pada remaja, berdasarkan beberapa penelitian yaitu dapat disebabkan oleh berbagai faktor. Diantara faktor penyebab dari perilaku agresif tersebut yaitu adanya faktorfaktor risiko seperti ciri-ciri biologis individu, tidak efektifnya pengasuhan, penolakan kelompok sebaya, dan bergaul dengan teman yang antisosial, kemiskinan, dan peristiwa kehidupan yang penuh stres (Saklofske \& Zeidner, 2009). Dan pendapat lain mengemukakan bahwa perilaku agresif disebabkan interaksi antara faktor biologis, psikologis, dan sosial budaya (Stuart, 2016). Serta perilaku agresif juga dapat disebabkan oleh pemodelan, pengkondisian, gangguan neurofisiologis, faktor biokimia, faktor sosial, ekonomi, dan faktor lingkungan (Townsend, 2015).

Berdasarkan teori dan beberapa penelitian sebelumnya menunjukkan bahwa remaja kecenderungan mengalami perilaku agresif. Maka hal ini menunjukkan bahwa perilaku agresif cenderung banyak terjadi pada masa remaja karena remaja berada di tahapan sangat penting dalam daur kehidupan dimana terjadi perubahan fisik dan psikologis yang sangat mendasar, sehingga mengalami kesulitan mengelola emosi dan perilaku yang dapat terjadi akibat belum memiliki pengalaman koping yang efektif. Dengan ini remaja mengalami perilaku agresif karena adanya naluri alamiah (instinng theory) yang terakumulasi dalam dirinya dan mengalami kesulitan menemukan cara melepaskan dengan kegiatan positif. Dan juga karena kesulitan dalam mengkomunikasikan dan tidak terpenuhi kebutuhan dasar (drive theory); serta belajar dari interaksi dengan lingkungan (social learning theory).

Karakteristik perilaku agresif remaja pada penelitian ini yaitu dikelompokan berdasarkan teori Buss-Perry, yang terdiri dari karakteristik dari agresi fisik, agresi verbal, kemarahan, dan permusuhan (Gallagher \& Ashford, 2016). Karakteristik perilaku agresif yang pertama yaitu agresi fisik (physical aggression) merupakan kecenderungan individu untuk melakukan serangan secara fisik untuk mengekspresikan kemarahan. Bentuk perilaku serangan fisik yang dilakukan individu yaitu dapat berupa memukul, mendorong, menendang, mencubit dan lain sebagainya. Pengukuran dengan menggunakan $B P A Q$ yang terdiri dari 9 item pernyataan dengan rentang nilai 9 sampai 45. Hasil penelitian ini menunjukkan skor agresi fisik yaitu 26,98 (tabel 4), dengan kesimpulan bahwa agresi fisik yang dialami cenderung tinggi. Hasil ini tidak jauh berbeda dengan hasil penelitian di Iran bahwa agresi fisik rata-rata skor sebesar 67,24\% (Naser, 2014), dan penelitian Fitri, Intan, \& Luawo (2016) pada remaja di Jakarta bahwa $71 \%$ mengalami agresi fisik, penelitian China bahwa sebanyak 39,2\% mengalami agresi fisik sedang (Elmasry, Fouad, Khalil, \& Sherra, 2016). Dari penelitian di Amerika menunjukkan bahwa sebanyak $22,6 \%$ remaja melakukan pertarungan fisik yang merupakan bentuk perilaku agresif (Laura, 2016), \%), serta penelitian di India bahwa sebesar 46,04\% mengalami agresi fisik (Sharma \& Sangwan, 2016).

Penelitian ini tanda dan gejala agresi fisik yang paling banyak dialami oleh responden yaitu menggunakan kekerasan untuk melindungi diri dan mempertahankan hak, serta membalas jika orang lain memukul. Dari hasil penelitian ini, bahwa remaja mengalami kecenderungan untuk agresi fisik yaitu hampir separuh remaja melakukan kekerasan secara fisik dengan cara seperti memukul individu lain. Hal ini memperlihatkan bahwa remaja cenderung untuk mengekspresikan kemarahannya dengan melakukan serangan secara fisik. Karakteristik kedua dari perilaku agresif dalam penelitian ini yaitu agresi verbal (verbal aggression) merupakan kecenderungan untuk menyerang orang lain yang dapat merugikan dan menyakitkan kepada individu lain secara verbal, yaitu melalui kata-kata atau penolokan. 
Bentuk perilaku serangan verbal yang dilakukan individu yaitu dapat berupa cacian, ancaman, mengumpat, penolakan dan lain sebagainya. Pengukuran dengan menggunakan $B P A Q$ yang terdiri dari 5 item pernyataan dengan rentang nilai 5 sampai 25. Hasil penelitian ini menunjukkan skor agresi verbal yaitu rata-rata sebesar 14,58 (tabel 4), yang menunjukkan bahwa agresi verbal cenderung tinggi.

Hasil penelitian jenis agresi verbal ini sejalan dengan penelitian yang dilakukan Spanyol bahwa skor rata-rata agresi verbal yaitu 57,60\% (Rubio-Garay, Carrasco, \& Amor, 2016), juga konsisten dengan hasil penelitian di Iran bahwa menunjukkan skor rata-rata agresi verbal sebesar $57,52 \%$ (Naser, 2014). Hasil ini juga tidak jauh beda dengan penelitian di India yaitu sebesar 38,80\% agresi verbal sedang dan $46,40 \%$ agresi verbal tinggi (Sharma \& Sangwan, 2016), serta penelitian di India juga bahwa remaja laki-laki sebesar $55,5 \%$ mengalami agresi verbal sedang dan $21,5 \%$ agresi verbal tinggi, dan remaja perempuan sebesar 57,5\% mengalami agresi verbal sedang, $13 \%$ agresi verbal tinggi (Kumari \& Kaur Kang, 2017). penelitian di Nigeria juga menunjukkan bahwa sebesar 48,3\% remaja mengalami perilaku agresif verbal (Onukwufur, 2013). Akan tetapi hasil penelitian ini sedikit berbeda dengan penelitian Fitri, Intan, \& Luawo (2016) pada remaja di Jakarta bahwa $72 \%$ mengalami agresi verbal, karena sampel yang digunakan yaitu remaja laki-laki dan sampelnya lebih banyak. Dan juga berbeda dengan penelitian di Rusia bahwa agresi verbal yang remaja mencapai hampir 80\% (Kasimova \& Biktagirova, 2016), hal ini berbeda karena penelitian ini menggunakan metodelogi yang berbeda dalam menentukan jenis agresi serta jumlah sampel lebih banyak.

Penelitian ini tanda dan gejala agresi verbal yang paling banyak dialami oleh responden yaitu memberitahu secara terang-terangan jika tidak setuju dan cepat untuk bereaksi tapi cepat reda. Dari hasil penelitian ini, bahwa remaja mengalami kecenderungan untuk agresi verbal yaitu hampir separuh remaja melakukan kekerasan secara verbal dengan cara seperti penolakan secara terang-terangan dan cepat bereaksi. Hal ini memperlihatkan bahwa remaja cenderung untuk mengekspresikan kemarahannya dengan melakukan serangan secara verbal.
Karakteristik ketiga dari perilaku agresif pada penelitian ini yaitu kemarahan (anger) merupakan perasaan marah, kesal, atau kecenderungan untuk marah dan kesulitan untuk mengendalikan amarah. Pengukuran dengan menggunakan $B P A Q$ yang terdiri dari 7 item pernyataan dengan rentang nilai 7 sampai 35. Hasil penelitian ini menunjukkan skor kemarahan pada responden yaitu skor rata-rata yaitu 20,44 (tabel 4). Hasil ini tidak jauh berbeda dengan hasil penelitian di Iran bahwa kemarahan rata-rata skor sebesar 22,04 (Naser, 2014). Juga sejalan dengan hasil penelitian di Turkey bahwa skor rata-rata kemarahan yaitu sebesar $55,40 \%$ (Kaya \& Buzlu, 2016), dan penelitian Fitri, Intan, \& Luawo (2016) pada remaja di Jakarta bahwa $59 \%$ mengalami kemarahan.

Penelitian ini tanda dan gejala kemarahan yang termasuk banyak dialami oleh responden yaitu tidak bisa menguasai diri, kesulitan mengendalikan kemarahan, dan pendapat orang bahwa saya pemarah. Dari hasil penelitian ini, menunjukkan bahwa remaja mengalami kecenderungan untuk kemarahan seperti tidak mampu menguasai diri menghadapi situasi yang menyebabkan kemarahan, dan kesulitan dalam mengendalikan kemarahannya.

Karakteristik keempat dari perilaku agresif dalam penelitian ini yaitu permusuhan (hostility) merupakan perilaku agresif yang tidak terlihat seperti individu mengalami kebencian, dendam, cemburu, iri, ketidakpercayaan, dan kekhawatiran terhadap orang lain. Pengukuran dengan menggunakan $B P A Q$ yang terdiri dari 8 item pernyataan dengan rentang nilai 8 sampai 40. Hasil penelitian ini menunjukkan skor permusuhan pada responden rata-rata sebesar 24,75 (tabel 4). Hasil penelitian ini sesuai dengan hasil penelitian di Iran bahwa permusuhan rata-rata skor sebesar 25,55 (Naser, 2014). Serta sedikit berbeda dengan penelitian Fitri, Intan, \& Luawo (2016) pada remaja di Jakarta bahwa 77,3\% mengalami permusuhan, karena sampel yang digunakan yaitu hanya remaja laki-laki dan jumlah sampel yang digunakan lebih banyak dibandingkan penelitian ini.

Penelitian ini tanda dan gejala permusuhan yang termasuk banyak dialami oleh responden yaitu merasa orang lain sering membicarakan dibelakang, curiga terhadap seseorang yang berbuat baik, dan merasa orang lain sering 
mentertawakan dibelakang. Dari hasil penelitian ini, menunjukkan bahwa remaja mengalami kecenderungan untuk permusuhan seperti adanya perasaan curiga dan ketidakpercayaan terhadapat orang lain. Berdasarkan hasil penelitian serta penjelasan diatas (tabel 4) perilaku agresif remaja pada sekolah menengah kejuruan " $\mathrm{X}$ " di Kota Padang, bahwa karakteristik perilaku agresif yaitu permusuhan dan agresi fisik. Perilaku yang diperlihatkan remaja terkait dengan karakteristik permusuhan antara lain merasa orang lain sering membicarakan dibelakang, curiga terhadap seseorang yang berbuat baik, dan merasa orang lain sering mentertawakan dibelakang. Sedangkan perilaku yang diperlihatkan remaja terkait dengan karakteristik permusuhan antara lain menggunakan kekerasan untuk melindungi diri dan mempertahankan hak, serta membalas jika orang lain memukul.

Berdasarkan hasil penelitian ini bahwa perilaku agresif remaja cenderung tinggi, maka untuk mengatasi perilaku agresif pada remaja perlu dilakukan berbagai upaya dengan memperhatikan dimensi perkembangan pada usia remaja seperti perkembangan biologi, psikoseksual, kognitif, moral, bahasa, emosi, psikososial, spiritual dan kreativitas. Sehingga upaya-upaya yang akan dikembangkan dan dilaksanakan dapat dipahami remaja dengan mudah dan baik. Serta pada saat upaya telah dilaksanakan maka remaja yang mengalami perilaku agresif mampu mengatasi berbagai penyebab masalah dan memiliki ketangguhan (Riekert, 2014). Salah satu intervensi yang dapat dilakukan adalah $A R T$ yang merupakan latihan keterampilan sosial, latihan manajemen marah dan penalaran moral (Hornsveld, Kraaimaat, Muris, Zwets, \& Kanters, 2015; Brännström, Kaunitz, Andershed, South, \& Smedslund, 2016; Kaya \& Buzlu, 2016). Implikasi penelitian yaitu menambah bahan penelitian tentang perilaku agresif pada remaja, pihak terkait memperoleh gambaran perilaku agresif siswa, dapat digunakan sebagai data dasar, pembanding dan landasan untuk penelitian selanjutnya dengan ruang lingkup dan metodelogi yang sama ataupun berbeda untuk pengembangan penelitian keperawatan.

\section{SIMPULAN}

Rerata perilaku agresif remaja di sekolah menengah kejuruan " $X$ " Kota Padang cenderung tinggi, dengan karakteristik perilaku permusuhan dan agresi fisik.

\section{DAFTAR PUSTAKA}

Allen, J. J., \& Anderson, C. A. (2017). Aggression and Violence: Definitions and Distinctions. In The Wiley Handbook of Violence and Aggression. https://doi.org/10.1002/9781119057574. whbva001

Blakemore, S., \& Mills, K. L. (2014). Is Adolescence a Sensitive Period for Sociocultural Processing? (August 2013), 1-21. https://doi.org/10.1146/annurev-psych010213-115202

Brännström, L., Kaunitz, C., Andershed, A. K., South, S., \& Smedslund, G. (2016). Aggression replacement training (ART) for reducing antisocial behavior in adolescents and adults: A systematic review. Aggression and Violent Behavior, 27, 30-41. https://doi.org/10.1016/j.avb.2016.02.00 6

Elmasry, N. M., Fouad, A. A., Khalil, D. M., \& Sherra, K. S. (2016). Physical and verbal aggression among adolescent school students in Sharkia, Egypt: prevalence and risk factors. Egyptian Journal of Psychiatry, 166-173. https://doi.org/10.4103/11101105.195547

Enopadria, C. (2018). Analisis faktor yang berhubungan dengan perilaku agresif pada remaja di Kota Padang Sumatera Barat tahun 2018. Universitas Andalas.

Evren, C., Çinar, Ö., Güleç, H., Çelik, S., \& Evren, B. (2011). The validity and reliability of the Turkish version of the Buss-Perry's aggression questionnaire in male substance dependent inpatients. Dusunen Adam, 24(4), 283-295. https://doi.org/10.5350/DAJPN2011240 404

Fagel, S., \& Sonneville, L. De. (2013). SchoolAssociated Problem Behavior in Childhood and Adolescence and Development of Adult Schizotypal Symptoms: A Follow-Up of a Clinical Cohort. https://doi.org/10.1007/s10802- 


\section{3-9829-6}

Fasya, H., \& Friska Amelia, A. (2017). Pengaruh Game Online Terhadap Tingkat Agresivitas Anak-anak dan Remaja di Kota Makassar (Studi Kasus di Kecamatan Tallo). Hasanuddin Student Journal, 1(2), 127-134.

Fitri, S., Intan, M., \& Luawo, R. (2016). Gambaran Agresivitas Pada Remaja Laki-laki Siswa SMA Negeri di DKI Jakarta. Jurnal Bimbingan Dan Konseling, 5(2), 155-168.

Gallagher, J. M., \& Ashford, J. B. (2016). Buss-Perry Aggression Questionnaire: Testing Alternative Measurement Models With Assaultive Misdemeanor Offenders. Criminal Justice and Behavior, 43(11), 1639-1652. https://doi.org/10.1177/0093854816643 986

Gentile, D. A., Coyne, S., \& Walsh, D. A. (2011). Media violence, physical aggression, and relational aggression in school age children: A short-term longitudinal study. Aggressive Behavior, $37(2)$, 193-206. https://doi.org/10.1002/ab.20380

Hall, C. et.al. (2012). Understanding aggressive behaviour across the lifespan. https://doi.org/10.1111/j.13652850.2012.01902.x

Hayman, E. L. (2016). Reducing verbal and physical aggression in elementary students with Autism Spectrum Disorder using the Aggression Replacement Training Program. The Sciences and Engineering, 77.

Holder, M. K., \& Blaustein, J. D. (2014). Frontiers in Neuroendocrinology Puberty and adolescence as a time of vulnerability to stressors that alter neurobehavioral processes. Frontiers in Neuroendocrinology, 35(1), 89-110. https://doi.org/10.1016/j.yfrne.2013.10.0 04

Hornsveld, R. H. J., Kraaimaat, F. W., Muris, P., Zwets, A. J., \& Kanters, T. (2015). Aggression Replacement Training for Violent Young Men in a Forensic
Psychiatric Outpatient Clinic. Journal of Interpersonal Violence, 30(18), 31743191.

https://doi.org/10.1177/0886260514555 007

Ivacevich, L., \& Gabriela, M. (2011). The Buss-Perry Aggression Questionnaire: Construct validity and gender invariance among Argentinean adolescents Cuestionario de Agresión de Buss-Perry: validez de constructo e invarianza de género en.

Kanne, S. M., \& Mazurek, M. O. (2011). Aggression in children and adolescents with ASD: Prevalence and risk factors. Journal of Autism and Developmental Disorders, 41(7), 926-937. https://doi.org/10.1007/s10803-010$1118-4$

Kasimova, R. S., \& Biktagirova, G. F. (2016). Art therapy as a means of overcoming aggressiveness in adolescents. Mathematics Education, 11(4), 902910.

Kaya, F., \& Buzlu, S. (2016). Effects of Aggression Replacement Training on Problem Solving, Anger and Aggressive Behaviour among Adolescents with Criminal Attempts in Turkey: A QuasiExperimental Study. Archives of Psychiatric Nursing. https://doi.org/10.1016/j.apnu.2016.07.0 01

Kumari, V., \& Kaur Kang, T. (2017). Relationship between Aggressive Behaviour and Parenting Style. International Journal of Current Microbiology and Applied Sciences, 6(5), 1224-1231. https://doi.org/10.20546/ijcmas.2017.60 5.132

Kusumaryani, M. (2017). Ringkasan Studi: Prioritas kesehatan reproduksi remaja untuk menikmati bonus demografi. Retrieved from www.ldfebui.org

Laura, K. et.al. (2016). Youth Risk Behavior Surveillance - United States, 2015. https://doi.org/http://dx.doi.org/10.1558 5/mmwr.ss6506a 1 
Marcus, R. F. (2017). The development of aggression and violence in adolescence. In The Development of Aggression and Violence in Adolescence. https://doi.org/10.1057/978-1-13754563-3

Martin, et.al. (2018). Lewis's Child and Adolescent Psychiatry: A Comprehensive Textbook (Fifth Edit). Philadephia: Wolters Kluwer.

Mokdad, A. H., Forouzanfar, M. H., Daoud, F., Mokdad, A. A., Bcheraoui, C. El, Moradi-lakeh, M., ... Saud, K. (2016). Global burden of diseases, injuries, and risk factors for young people' $s$ health during 1990 - 2013 : a systematic analysis for the Global Burden of Disease Study 2013. 6736(16), 1-19. https://doi.org/10.1016/S01406736(16)00648-6

Naser, A.et.al. (2014). Comparing the dimensions of aggression in adolescent athletes and non- athletes divorced families. European Journal of Experimental Biology, 4(1), 452-455.

Onukwufur, J. (2013). Physical and Verbal Aggression Among Adolescent Secondary School in Rivers State of Nigeria. International Journal of Education Learning and Development, 1(2), 73-84. Retrieved from www.eajournals.org

Pechorro, P., Barroso, R., Poiares, C., Oliveira, J. P., \& Torrealday, O. (2016). Validation of the Buss-Perry Aggression Questionnaire-Short Form among Portuguese juvenile delinquents. International Journal of Law and Psychiatry, 44, 75-80. https://doi.org/10.1016/j.ijlp.2015.08.03 3

Pitakasari, A. A., Kandar, \& Pambudi, A. (2017). Hubungan Paparan Game Online Berunsur Kekerasan Terhadap Relationship Of Online Game Exposure To Violence Towards Agressive Behavior In Adolescents. Jurnal Ilmiah Konseling, 5, 96-102. Retrieved from https://jurnal.unimus.ac.id/index.php/JK J/article/view/4493
Rajasakran, T., Wong, A. K. C., Sinnappan, S., Pangiras, G., \& Koran, S. (2014). Aggressor Games: Of Violent Video Games and Aggression among Higherincome Group Schoolchildren in Malaysia. Science Technology \& Society, 19:3, 383-398. https://doi.org/10.1177/0971721814548 113

Riekert, et.al. (2014). The Handbook of Health Behavior Change (4th editio). Retrieved from www.springerpub.com

Rubio-Garay, F., Carrasco, M. A., \& Amor, P. J. (2016). Aggression, anger and hostility: Evaluation of moral disengagement as a mediational process. Scandinavian Journal of Psychology, 57(2), 129-135. https://doi.org/10.1111/sjop.12270

Saklofske, D. H., \& Zeidner, M. (2009). Treating Child and Adolescent Aggression Through Bibliotherapy (The Springer Series on Human Exceptionality). https://doi.org/10.1007/978-0-38709745-9

Salmiati. (2015). Perilaku Agresif Dan Penanganannya (Studi Kasus Pada Siswa SMP Negeri 8 Makassar). Jurnal Psikologi Pendidikan \& Konseling, 1(1), 66-76.

Santrock, J. W. (2011). Life-span development. https://doi.org/10.1037/002921

Schultz, P., \& Duane, S. E. S. (2016). Teori Kepribadian (10th ed.; A. K. Putra, Ed.). Jakarta: EGC.

Sentana, et.al. (2017). Agresivitas dan kontrol diri pada remaja di Aceh. Jurnal Sains Psikologi, (November), 51-55.

Sharma, D., \& Sangwan, S. (2016). Physical, verbal and relational aggression among adolescents. Advance Research Journal of Social Science, 6(2), 160-164. https://doi.org/10.15740/has/arjss/6.2/16 $0-164$

Stuart, G. W. (2016). Prinsip dan Praktik Keperawatan: Keperawatan Kesehatan Jiwa Stuart (Edisi Indo; K. Budi Anna, Ed.). Singapore: Elsevier (Sigapore) 
Pte.Ltd.

Tobergte, D. R., \& Curtis, S. (2013). The Research Process in Nursing. In Journal of Chemical Information and Modeling (Vol. $53)$. https://doi.org/10.1017/CBO978110741 5324.004

Townsend, M. (2015). Psychiatric Mental Health Nursing: Concepts of Care in Evidence-Based Practice (Eighth Edi). Retrieved from www.fadavis.com

Utami, T. W., Fadilah, A., \& Livana. (2019). The Relationship Between Bullying Andhelplessness In Adolescent. Jurnal Keperawatan Jiwa, 1, 159-164. Retrieved from https://jurnal.unimus.ac.id/index.php/JK J/article/view/4897

Utami, T. W., \& Nurhayati, F. (2019). Kecanduan Internet Berhubungan Dengan Interaksi Sosial Internet Addiction Is Related To Social Interaction In Adolescent. Jurnal Keperawatan Jiwa, 7, 33-38. Retrieved from https://jurnal.unimus.ac.id/index.php/JK $\mathrm{J} /$ article/view/4615

Valdivia-Peralta, M., Fonseca-Pedrero, E., González-Bravo, L., \& Lemos-Giráldez, S. (2014). Psychometric properties of the AQ Aggression Scale in Chilean students. Psicothema, 26(1), 39-46. https://doi.org/10.7334/psicothema2013. 84

Wallace, M., \& Joyce, J. (2012). Encylopedia of Nursing Research.

WHO. (2015). World health statistics 2015. Retrieved from www.who.int

WHO. (2016). Youth Violence. Retrieved from http://www.who.int/en/news-room/factsheets/detail/youth-violence

Zhang, Y., Wu, C., Yuan, S., Xiang, J., Hao, W., \& Yu, Y. (2018). Association of aggression and suicide behaviors: A school-based sample of rural Chinese adolescents. Journal of Affective Disorders.

https://doi.org/10.1016/j.jad.2018.07.02 